\title{
Ewelina Suszek
}

Państwowa Wyższa Szkoła Zawodowa w Tarnowie

(iD) http://orcid.org/0000-0002-6574-5842

\section{Nad kulturową mapą cierpienia}

\section{Beyond the Cultural Map of Suffering}

Abstract: This article provides critical context for, and an analysis of, Sebastian Porzuczek's The Mapping of Pain: Reading - Gaze - Affect (Mapowanie bólu. Lektura - spojrzenie - afekt). Porzuczek's study is an literary-anthropological project that aims to characterize the cultural conceptualization of pain in modernity - and, to a lesser extent, in postmodernity - through interpretations of mainly-European literary and film works. This article analyses The Mapping of Pain against a backdrop of earlier Polish research in the humanities. The reading of this book inspires further questions connected with Cartesian dualism, the ethical implications of the distinction between pain and suffering, and also the influences of the COVID-19 pandemic (bringing forth the concept of the viral epidemic from the margins of the attention of the postmodern world) upon today's society.

Key words: pain, suffering, (post)modernistic culture, mapping

Streszczenie: Artykuł o charakterze analityczno-krytycznym stanowi omówienie książki Mapowanie bólu. Lektura - spojrzenie - afekt Sebastiana Porzuczka. Studium Porzuczka to antropologiczno-literaturoznawczy projekt, którego celem jest zaprezentowanie kulturowego ujęcia bólu w nowoczesności oraz w mniejszym stopniu - ponowoczesności poprzez interpretację głównie europejskich dzieł literackich i - rzadziej - filmowych. Mapowanie bólu zostaje zanalizowane na tle innych polskich badań humanistycznych w tym zakresie. A jego odczytanie prowokuje autorkę do zadawania dalszych pytań, przykładowo dotyczących dualizmu Kartezjańskiego, etycznych skutków rozróżnienia między bólem a cierpieniem oraz wpływów pandemii COVID-19 (wyprowadzającej chorobę z marginesu ponowoczesnego świata) na dzisiejszą wspólnotę.

Słowa kluczowe: ból, cierpienie, (post)modernistyczna kultura, mapowanie 
Czemu może służyć mapa doloropoetyki i czy rzeczywiście potrzebujemy jej w kolejnych ekspedycjach humanistów? Książka Mapowanie bólu. Lektura - spojrzenie - afekt Sebastiana Porzuczka nie tylko zasługuje na pochylenie się nad nią, ale także na wnikliwe przestudiowanie ${ }^{1}$. Powinna wzbudzić zainteresowanie zwłaszcza czytelników (zapewne reprezentantów rozmaitych dyscyplin naukowych), którzy podążają tropem kategorii: cierpienia/bólu, choroby, ciała, podmiotowości, empatii, spojrzenia, odbioru afektywnego, tranzytowości doświadczeń granicznych oraz kultury nowoczesnej i ponowoczesnej. Już samo wymienienie tych obszarów sygnalizuje, że autor zakreśla pole badawcze z dużym rozmachem. Rozmach zaś stanowi pierwszy dowód na słuszność doboru tytułu. Warto przypomnieć, że łacińskie słowo mappa znaczy 'serweta', a etymologia ta ma podkreślać przede wszystkim jedną właściwość przedmiotu: szerokość․ I taki też - szeroki - jest ten antropologiczno-literaturoznawczy projekt.

Ambicją Porzuczka jest zaprezentowanie kulturowego ujęcia bólu w nowoczesności oraz - w mniejszym stopniu - ponowoczesności poprzez analizę i interpretację głównie europejskich dzieł literackich i - rzadziej - filmowych. Nawet jeśli nie jest to prekursorski kierunek (monografia wpisuje się w jeden $\mathrm{z}$ najbardziej popularnych trendów badawczych polskiej humanistyki ostatnich lat), należy docenić zarówno interesujące interpretacje, jak i to, że praca znacząco poszerza stan badań w tym wymiarze i dotyczy doświadczeń niezaprzeczalnie ważnych dla każdego istnienia, a jednocześnie trudnych do opisu.

Na mapie Porzuczka „trasę” wyznacza kilka punktów. Jej pierwszy etap pozwala czytelnikom zapoznać się z syntetycznie ukazanymi przemianami w traktowaniu cierpienia, różnicami zachodzącymi między nowoczesnością i ponowoczesnością. Następny przedstawia interpretację dzieł prozatorskich: Piotrusia (Apokryfu) Leo Lipskiego, Oddechu. Wyzwolenia i Chłodu. Izolacji Thomasa Bernharda, Dziennika, Pornografii, Opętanych Witolda Gombrowicza oraz jednego filmu Miłości w reżyserii Michaela Hanekego. W finale monografii autor, sięgając po jeszcze inne teksty kultury, zakreśla typografię doloropoetyki. Każda z tych części jest ciekawa, każda jest godna uwagi i każda prowokuje do zadawania pytań.

${ }^{1}$ Zob. S. Ponzuczeк: Mapowanie bólu. Lektura - spojrzenie - afekt. Kraków 2020. Wszystkie cytacje czerpię z tego wydania, w tekście lokalizuję je przez podanie strony.

${ }^{2}$ Zob. A. Brückner: Mapa. W: Idem: Stownik etymologiczny języka polskiego. Warszawa 1985, s. 322. 
Punktem wyjścia rozważań Porzuczka jest krytyka mechanistycznego modelu bólu rozwijanego w ramach Kartezjańskiej dychotomii duszy (umysłu) i ciała. Znajduje ona swoją wyraźną kontynuację w części poświęconej lekturze prozy Lipskiego, ale jej odbicie można dostrzec także $\mathrm{w}$ innych partiach, $\mathrm{np}$. w rozdziale dotyczącym opowiadań Thomasa Bernharda. Teoria bezpośredniej, fizycznej odpowiedzi na impuls nie zadowala autora, ponieważ nie uwzględnia całościowej dominacji bólu nad podmiotem oraz społecznych efektów chorowania. Bliższa więc wydaje mu się koncepcja Paula Ricœura, w której obciążony cierpieniem przemienia się w „żywą ranę" (s. 11). Przypuszczam, że pokrewieństwo stanowisk mógłby odnaleźć także w ujęciu Tadeusza Sławka - w eksponowanej przez niego formule ,jja bolę", sygnalizującej potęgę bólu, który wszechogarnia, zakłóca codzienność, zmienia relacje ze światem i dokonuje totalnego przewrotu $\mathrm{w}$ tożsamości cierpiącego ${ }^{3}$. Warto tutaj także nadmienić, że krytykę Kartezjańskiej teorii w polskiej humanistyce przeprowadziła już wcześniej Iwona Boruszkowska w studium poruszającym bliźniaczą tematykę, do którego Porzuczek się jednak nie odwołuje. Nie można zatem powiedzieć, że autor jest jakkolwiek osamotniony w swoim sprzeciwie wobec takiej konceptualizacji bólu, uznawanej dziś już za anachroniczną.

Po inspirującej lekturze Mapowania bólu zaczynają mnie nurtować pewne kwestie. Frapuje pytanie: jak wyjaśnić utrzymującą się przez ponad trzysta lat popularność teorii Kartezjusza zarówno w dyskursie akademickim, jak i w powszechnej świadomości? ${ }^{5}$ Czy wynikała ona jedynie ze stanu współczesnej wiedzy i nowożytnej fascynacji mechanicyzmem, dostrzeganej $\mathrm{w}$ tak licznych dziedzinach? Czy to jeszcze echo tradycji średniowiecznej, której pierwiastki wciąż są przecież obecne w kartezjanizmie? Myślę szczególnie o filozofii Augustyna z Hippony, izolującej duszę od funkcji biologicznych ${ }^{6}$,

${ }^{3}$ Zob. T. SŁAweK: "Ja bolę". Boleść i terapia. W: Fragmenty dyskursu maladycznego. Red. M. Ganczar, I. Gielata, M. Ładoń. Gdańsk 2019, s. 89-107. Por. M. ОкupNIK: W niewoli ciała. Doświadczenie utraty zdrowia i jego reprezentacje. Kraków 2018, s. 82.

${ }^{4}$ Zob. I. BoruszKowska: Sygnatury choroby. Literatura defektu w ukrainskim modernizmie. Warszawa 2018, s. 54-56. Literaturoznawczyni opiera swoje analizy na: B. Gert, Ch.M. Culver, K. Denner Clouser: Bioetyka. Ujęcie systematyczne. Przeł. M. Снолnacki. Gdańsk 2009, s. 182.

${ }^{5}$ Sebastian Porzuczek, śledząc dzieje tej koncepcji, opiera się na: J. Bourke: The Story of Pain. From Prayer to Painkillers. Oxford 2014, s. 13, 241.

${ }^{6}$ Por. W. Tatarkiewicz: Historia filozofii. T. 1: Filozofia starożytna i średniowieczna. Warszawa 2004, s. 198. Filozof z Hippony pisał: „Nie sądzę, że dusza czegoś 
ale także o wszystkich platońsko-chrześcijańskich praktykach uznawania wyższości duszy nad materią. A może redukcja cierpienia do biologicznej reakcji na bodziec po prostu niosła pociechę, ponieważ była wariantem łatwiejszym do zniesienia niż wizja zniewalającego bólu, w całości atakującego ,ja", angażującego nie tylko układ nerwowy, ale i promieniującego na wszelkie aspekty ludzkiej egzystencji?

Stanowczość, z jaką Porzuczek neguje model myśliciela (z wyjątkiem - jak sam przyznaje - błyskotliwego powiązania bólu z przyjemnością), sprawia, że zapewne nieco przekornie uwrażliwiam się na podobieństwa łączące jego refleksję z autorem Rozprawy o metodzie. Dostrzegam dwa - subtelne. Według Kartezjusza, bodaj najsłynniejszego zwolennika racjonalizmu, myśliciela twierdzącego, iż filozofia ma także służyć ochronie zdrowia ${ }^{7}$ - ciało (podobnie jak wcześniej głosił to św. Augustyn ${ }^{8}$ ) jest zdecydowanie trudniej poznać niż duszę̧, a więc pole substancji rozciągłej stanowi obszar większych zagadek. Owa tajemniczość doznań zostaje zaakcentowana już w pierwszym zdaniu Mapowania bólu - książki, której autor - warto mocno podkreślić - dąży do precyzji i znakomicie operuje współczesną aparaturą pojęciową, dbając o wszystkie zasady naukowości. Czytamy zatem: „Ból - jako fenomen powszechny dla istot żywych - to jedno z najbardziej ważkich i jednocześnie tajemniczych - trudnych do dyskursywnego uchwycenia, doznań" (s. 9). Zapewne nie bez znaczenia jest też, że rozdział otwiera motto zaczerpnięte z Fali Johna Ashbery'ego: „Przejść przez ból i nic o tym nie wiedzieć..." (s. 9). Aura czegoś niepoznawalnego unosi się nad całą książką. Przyglądam się więc, w jaki sposób w szkicowaniu mapy Porzuczek posługuje się słowem "tajemnica". I tak dla przykładu

od ciała doznaje, natomiast sądzę, że działa na nie i w nim jako w poddanym z woli Bożej jej władzy”; „Wszelkie zatem rzeczy materialne, które z zewnątrz dostają się do naszego ciała lub z nim się stykają, wywołują zmiany nie w duszy, lecz w ciele". św. Augustyn: Dialogi filozoficzne. Przeł. A. Świderkówna. Kraków 1999, s. 678. Na zbieżności w pismach średniowiecznego myśliciela i Kartezjusza zwracano już uwagę. Zob. m.in. Z. Janowski: Index augustino-cartésien. Textes et commentaire. Paris 2000; T. ŚLIwiński: Źródła filozofii Descartes'a w myśli św. Augustyna. „Acta Universitatis Lodziensis Folia Philosopica” 2011, nr 24, s. $45-72$.

7 Zob. R. Descartes: Zasady filozofii. Przeł. I. Dąmbska. Warszawa 1960, s. 355-357.

${ }^{8}$ Por. W. Tatarkiewicz: Historia filozofii..., s. 198.

9 Zob. R. Descartes: Rozprawa o metodzie. Przeł. T. Boy-Żeleński. Warszawa 2008, s. 72 i nast. 
w świecie przedstawionym Gombrowicza: „Stan innego pozostaje tajemnicą" (s. 127), nie do pełnego odczytania jest bowiem spojrzenie cierpiącego przez tego, kto nie cierpi. Chorzy w opowiadaniach Bernharda sami mają kłopot ze zrozumieniem swoich doznań, które jawią się jako „wywołująca rozpacz tajemnica” (s. 208). A nawet jeśli bywają już „wtajemniczeni w zagadki ciała” (s. 66), "tajemnicze” pozostaje dla nich lekarskie „słowo-wyrok” (s. 63). Wobec nieufności względem medyków i ich języka doświadczeni druzgocącym bólem bohaterowie powieści Śmierć. Studium Ignacego Dąbrowskiego próbują wyczytać prawdę z "tajemniczych, niecodziennych zachowań, gestów" bliskich (s. 194). Nadal jednak zapadanie w nicość jest dla nich "niepojętą abstrakcją" (s. 197). W świetle tych cytacji nie dziwi, że tak istotna sprawa tranzytowości cierpienia, zwłaszcza artystyczne możliwości jego oddania, literackie i filmowe próby przełamania komunikacyjnego impasu (ale i pokusy teatralizacji bólu), np. dzięki transmisji afektów, stanowią główne zagadnienie badawcze monografii.

Warto tu nadmienić, że autor wskazuje na możliwe rozróżnienie między niedyskursywnym, somatycznym bólem a podlegającym symbolizacji cierpieniem, wzbudzającym konotacje ideologiczno-religijne. Zaraz jednak mu się mocno sprzeciwia jako pokłosiu kartezjańskiej antynomii. W konsekwencji ból i cierpienie traktuje synonimicznie (lojalnie powtarzam tę strategię). Zachowanie opozycji, mimo że różnica jest uchwytna na gruncie etymologii, uznaje za niemoralne, ponieważ potencjalnie wzmaga wstyd lub poczucie winy u cierpiącego (ból jako kara). Problem ten jest niezwykle trudny do rozpatrzenia - dla harmonijnej przeciwwagi przywołuję stanowisko odmienne:

Osoba ludzka przeżywa ból wszechogarniający w obszarach: somatycznym, psychicznym i duchowym [...]. Duchowym następstwem bólu [...] jest cierpienie, którego nie należy utożsamiać z bólem. Podstawowa różnica polega na tym, że ból jest doznawany, a cierpienie przeżywane. Nie można go złagodzić za pomocą środków farmakologicznych, a jedynie oferując choremu wsparcie duchowe. Polega ono przede wszystkim na towarzyszeniu i kompetentnej obecności ${ }^{10}$.

${ }^{10}$ J. Pyszkowska: Cierpienie chorych u kresu życia. W: W poszukiwaniu sensu cierpienia - dialog interdyscyplinarny. Red. ks. A. Bartoszeк. Katowice-Tarnów 2006, s. 28. Cyt. za: K. Wieczorek: Samotność bólu, ból samotności. „Ethos” 2017, nr 4, s. 34 (filozof także dopatruje się w takiej postawie absolutnie etycznej obecności). Za rozróżnieniem bólu od cierpienia opowiada się również Mieczysława 
Wypowiedzi Jadwigi Pyszkowskiej, lekarki specjalizującej się w medycynie paliatywnej, również trudno odmówić wrażliwości etycznej. Jest to bowiem wezwanie do odpowiedzialnego współbycia z chorym, bez wzbudzania choćby odrobiny winy czy wstydu.

Mapowanie bólu skłania mnie do refleksji nad monizmem i dualizmem. Nie wiem, czy autorowi udało się do końca porzucić ten drugi (czy można to w ogóle zrobić?). Wprawdzie opowiada się przeciwko dychotomii duszy (umysłu) i ciała oraz bólu i cierpienia, jednak wybór w swoich badaniach socjokulturowego ujęcia bólu każe zastanowić się nad tym, co nie zostało uwzględnione w tak przyjętej perspektywie (aspekt fizjologiczno-medyczny). Porzuczek pisze, że ból to „problem nie tylko dla medycyny (nauki), lecz również, a może przede wszystkim dla kultury: jako że cierpienie nie sprowadza się jedynie do fizycznej (biologicznej) reakcji na bodźce" (s. 9). Zawężenie pola badawczego, redukcja, do której oczywiście autor miał prawo, odsyła do antynomii kultura - natura/biologiczność, a ją można wszak uznać za przedłużenie zanegowanego dualistycznego porządku. Czyżby zatem rację mógł mieć Émile Durkheim? Czyżby człowiek jako homo duplex skazany był na podział - jeśli nie antynomię „ciało - dusza”, to "biologiczne - społeczne"11?

Trudno oczywiście przecenić rolę socjokulturowego wymiaru cierpienia, dostrzeżoną dość dobrze w polskiej humanistyce ${ }^{12}$. Znajduje ona także przekonujące potwierdzenie w pracy Porzuczka.

Gogacz. Zob. EAdem: Filozoficzne rozważania o rozpaczy i nadziei. „Studia Philosophiae Christianaes" 1983, nr 2, s. 159.

${ }^{11}$ Zob. É. Durкheim: Elementarne formy życia religijnego. System totemiczny w Australii. Przeł. A. Zadrożyńska. Warszawa 1990, s. 213. Por. J. Szacki: Historia myśli socjologicznej. Warszawa 2002, s. 377; S. Hınc: Émile Durkheim: edukacja moralna jako podstawa egzystencji. „Przegląd Naukowo-Metodyczny. Edukacja dla Bezpieczeństwa” 2008, nr 1, s. 13.

${ }_{12}$ Chociaż bibliografia dołączona do książki Sebastiana Porzuczka jest bardzo obszerna, brakuje mi kilku pozycji np.: M. Ładoń: Choroba jako literatura. Studia maladyczne. Katowice 2019; М. Окupniк: W niewoli ciała...; Ból. Red. A. Czekanowicz, S. Rosiek. Gdańsk 2004; K. Wieczorek: Samotność bólu..., s. 19-48; Kobieta, literatura, medycyna. Red. A. Galant, A. Zawiszewska. Szczecin 2016. Między Mapowaniem bólu a wymienionymi tekstami dostrzegam zarówno podobieństwo poruszanej problematyki, jak i wybranej metody badawczej. Kilka innych ciekawych propozycji niezawartych na mapie Sebastiana Porzuczka podpowiada Monika Ładoń. Zob. EAdem: Kartografia (Nie)możliwego. „artPapier” 2020, nr 13. http://artpapier.com/index.php?page=artykul\&wydanie=397\&artyku l=7948\&kat=15 [dostęp: 9.07.2020]. 
Już pierwszy rozdział przedstawia rozmaite strategie podejścia do bólu. Za typowe dla nowoczesności uznaje te, zaprezentowane przez Ernsta Jüngera w jego kanonicznym eseju. Są to: hartowanie w bólu (postawa żołnierska) lub umartwianie się w nim (postawa kapłańska) oraz jego eliminacja (strategia sentymentalna/burżuazyjna). Właśnie drogą wykluczenia bólu poszedł świat ponowoczesny, afirmujący farmakoterapię. Za Leszkiem Kołakowskim autor wskazuje, że efektem tego jest kryzys praktyk wspólnotowych i rozpad solidarności. To skłania dziś do zadania pytania, którego Porzuczek pisząc książkę - nie mógł jeszcze sformułować. Czy doświadczenie pandemii koronawirusa - stawiające pozbawioną wciąż skutecznego leczenia chorobę i jej skutki w centrum wszelkich dyskursów na całym świecie, a przez to wyprowadzające ból z marginesu ponowoczesnego świata - stwarza szansę odbudowy solidarności ${ }^{13}$ A może jedynie potęguje samotność jednostki, zwiększa ubóstwo i/lub prowadzi do narastania antagonizmów społecznych?

Porządek historyczny nie dominuje w pracy Porzuczka. W jej dalszych partiach niemal z niego zrezygnowano, co pozostawia niedosyt, zwłaszcza w części interpretacyjnej monografii. Autor wybiera figurę konstelacji na określenie organizacji myśli. Ma ona proweniencję adornowską. Pragnę jednak zauważyć, że Theodor Adorno nie porzuca perspektywy historycznej: „Postrzegać konstelację, w której znajduje się rzecz, to tyle co rozszyfrować tę konstelację, którą niesie ona w sobie jako coś historycznie wytworzonego. [...] Poznanie przedmiotu w jego konstelacji jest poznaniem procesu, który ten przedmiot w sobie zakumulowat"14. Autor tymczasem - redukując perspektywę historyczną i historycznoliteracką - najczęściej zdaje się traktować interpretowane teksty kultury jak osobne archipelagi lub też dość swobodnie przeskakuje morza epok, stylów, nurtów, odważnie niekiedy zestawiając dzieła pochodzące z różnych tradycji (np. polską powieść Śmierć Dąbrowskiego z 1893 roku i austriacką Mróz Bernharda z 1963 roku). Nieco zaskakuje, że na literackiej

${ }^{13} \mathrm{O}$ przemyśleniu porządku społecznego jako obowiązku intelektualnego na czas epidemii, także w odwołaniu do refleksji Leszka Kołakowskiego, wypowiada się Tadeusz SŁAweK. Zob. Idem: Nadzieja rozbitka. https://www.youtube. com/watch?feature=youtu.be\&v=Kk6eQNSk7uo\&fbclid=IwAR1qmkImVtRUZPk 5zK2ddOMD6OhlSKAC-cYM_Ck9maCEyBaPu4D3XA_TjXE\&app=desktop [dostęp: 30.05.2020].

${ }^{14}$ T.W. Adorno: Dialektyka negatywna. Przeł. K. Krzemieniowa. Warszawa 1986, s. 225-227. Cyt. za: R. Nycz: Lekcja Adorna. „Teksty Drugie” 2012, nr 3, s. 44 (na ten artykuł powołuje się również Sebastian Porzuczek). 
mapie, która ma służyć rekonesansowi, właściwie nie pojawią się kanoniczne dzieła, takie jak: Dżuma Alberta Camusa, Czarodziejska góra Tomasza Manna ani Sanatorium pod Klepsydra Brunona Schulza. Bywa, że nie ma nawiązań także do innych utworów omawianego pisarza. Dla przykładu: przemilczane zostaje, że motywy fekaliów, zamykania się $\mathrm{w}$ toalecie, dominacji kobiety nad mężczyzną występują nie tylko w Piotrusiu, lecz również w kilku pozostałych tekstach Lipskiego ${ }^{15}$. Bywa też, że Porzuczek powraca do pewnych wątków, plącze ścieżki analiz, zakreśla pętlę. Najpierw w interpretacjach używa określonej aparatury terminologicznej, a dopiero w zakończeniu książki referuje związaną z nią teorię (casus teorii afektów). Chociaż da się oczywiście zaobserwować gesty porządkujące (jak tworzenie tabel), zwolennicy chronologicznego porządku i tradycyjnej kompozycji studium mogą się momentami czuć trochę niekomfortowo. Wzorowanie się filozofią słabą ma uzasadnić „strukturę niespoistą, słabą" (s. 20) tej mapy.

Mapa (obok konstelacji) jest drugą figurą - konkurencyjną, a nawet bardziej uprzywilejowaną ze względu na tytuł ${ }^{16}$. Porzuczek pisze o „naszkicowanej ad hoc mapie myśli o doloropoetyce [podkr. - E.S.]” (s. 161) zapewne zbyt skromnie (lub kokieteryjnie?). Wszak mimo poczynionych uwag rozwiązania wybrane są świadomie, a wiele wniosków sprawia wrażenie bardzo przemyślanych. Jednocześnie przyznać należy, że, zgodnie z deklaracjami, Porzuczkowi udaje się uniknąć dążeń absolutystycznych - pragnień skonstruowania uniwersalnego modelu bólu przy założeniu, że potrafi się bez reszty scharakteryzować istotę cierpienia. W tym widzę różnicę między nim a Jüngerem, który w laboratorium „czystego cierpienia”, badając je ze zdystansowanym chłodem, starał się poznać jego logikę $e^{17}$. Zakładał więc istnienie analogii między człowiekiem a owadem $\mathrm{w}$ tym do-

${ }^{15}$ Mam na myśli utwory: Dzień i noc, Waadi, Niespokojni, Sarni braciszek. Por. J. Borowicz: Ciało we fragmentach, strzepki historii. Post-Zagładowe perwersje Leo Lipskiego. „Teksty Drugie” 2017, nr 2, s. 356-374; A. Lipszyc: Część śmierci: bierny frankizm i czarna gnoza w "Piotrusiu” Leo Lipskiego. „Teksty Drugie” 2017, nr 2, s. 339; M. Cuber: Proza Leo Lipskiego. Poetyka i egzystencja. Katowice 2006. https:// rebus.us.edu.pl/bitstream/20.500.12128/4960/1/Cuber_Proza_Leo_Lipskiego.pdf [dostęp: 31.05.2020].

${ }^{16}$ Warto zauważyć, że metaforą mapy w kontekście choroby i podmiotowości operowała już wcześniej (choć nie na taką skalę) Iwona BoruszKowsкA. Zob. EADEM: Sygnatury choroby..., s. 33.

${ }^{17}$ Moje odczytanie eseju $O$ bólu jest bliskie lekturze Łukasza MusiaŁa. Por. Idem: Laboratorium bólu (Ernst Jünger). W: IDEm: O bólu. Pięć rozważań w poszukiwaniu autora. Poznań 2016, s. 79, 91-92. 
znaniu $^{18}$. Tymczasem Porzuczek w interpretacji prozy Gombrowicza podkreśla gatunkową przepaść. $W$ ostatnim zdaniu książki za Italem Calvino mówi o „nikłym wspólnym mianowniku” (s. 214) w odczuwaniu bólu. Przekonują o nim także motta, które roztaczają rozmaite „widoki" na ból. Każdy rozdział otwiera motto lub - przeważnie konstelacja cytatów, zestawionych niekiedy w antytetyczny sposób (jak w przypadku słów Giacoma Leopardiego i Józefa Wittlina czy Emila Ciorana i Michela Foucaulta czy też Hannah Arendt i autora Brewiarza zwyciężonych). To dowód na to, że dyskurs maladyczny faktycznie jest „,wielogłosowy"19, „pojemny i otwarty"20.

Porzuczek kolejną metodologiczną inspirację odnajduje w tekście Nad mapa postmodernizmu Andreasa Huyssena, choć wskazania tego szerzej nie argumentuje. I tu jednak dostrzegam różnicę. „Kartografowie" w praktyce zaznaczania na terytorium badawczym centralnych strategii artystycznych wybierają odmienną skalę. Huyssen sporządza mapę w wielkiej skali. Porzuczek natomiast raz, owszem, „oddala”, a raz „przybliża”. Połączenie w pracy perspektywy mikro (w części interpretacyjnej) z makro (w rozdziałach okalających) uważam za sporą zaletę jego mapy.

Podoba mi się także pomysłowe wykorzystanie polisemii „mapy"l „mapowania”. Autor nawiązuje nie tylko do idei stworzenia typografii bólu, procesu nanoszenia go na mapę (po)nowoczesnej myśli, ale także do praktyki medycznej - „formy badania, opierającego się na stymulowaniu określonych części ciała (dotkliwym ingerowaniu $\mathrm{w}$ to, co wewnętrzne) $\mathrm{w}$ poszukiwaniu bolesnych punktów, z których powstać może mapa obszarów szczególnie wrażliwych, dokuczliwych, podatnych na podrażnienie" (s. 22). Poszukiwanie punktów wydaje mi się adekwatne do wcześniej wspomnianego traktowania dzieł literackich jak odrębnych archipelagów. Podkreślenie inwazyjności tej metody może jednak nieco niepokoić, zwłaszcza jeśli zestawi się je z innymi asocjacjami słowa „mapa”. Chciałabym tu przypomnieć ustalenia Elżbiety Konończuk - mapa jest „wyrazem kontroli”21, narzędziem „zdobywania nowych przestrzeni”22.

18 Zob. E. JüNGer: O bólu. Przeł. J. Proкоріuk. „Literatura na Świecie” 1986, nr 9, s. 179.

19 Tak o nim wypowiada się Mateusz Szubert. Zob. IDEm: Dyskurs maladyczny - perspektywy badawcze. W: Fragmenty dyskursu maladycznego..., s. 20.

${ }^{20}$ M. Ładoń: Ślady Barthes'a: migrena, symbolizacja, fragment (stowo wstępne). W: Fragmenty dyskursu maladycznego..., s. 9.

${ }^{21}$ E. Konończuк: Mapa w interdyscyplinarnym dialogu geografii, historii $i$ literatury. „Teksty Drugie” 2011, nr 5, s. 256.

${ }^{22}$ Ibidem, s. 260. 
Wprawdzie Porzuczek pisze o „eksploracji nieprzystępnej problematyki" (s. 214), lecz po wprowadzeniu medycznej definicji formułuje deklarację, która może uspokoić - eksperyment ma być rodzajem „nieśmiałego wy-badania” (s. 22). Notka Ryszarda Nycza na okładce książki mówi o „celowo zdystansowanej - acz zarazem empatycznej - analizie". To niewątpliwie duża umiejętność połączyć badawczy dystans ${ }^{23}$ i precyzję z taktem i empatią (wielokrotnie zresztą tematyzowaną w książce), jednocześnie bez poddania się „reżimowi sentymentalizmu" ${ }^{\prime 24}$.

Zauważam jeszcze jeden walor tytułu. Kategoria mapy skłania do refleksji nad trudem reprezentacji rzeczywistości (Jorge Luis Borges, Umberto $\mathrm{Eco})^{25}$, a kwestia artystycznego przedstawienia bólu jest - jak już wiadomo - nader istotna dla tego studium i to do tego stopnia, że wpływa na układ części interpretacyjnej. Porządek rozdziałów ustalono zgodnie $\mathrm{z}$ wzrastającą $\mathrm{w}$ utworach tranzytowością doświadczenia cierpienia. Dodatkowym kryterium jest perspektywa. Podróż, do której czytelnik zostaje zaproszony, zakłada przejście od skrajnego subiektywizmu (proza Lipskiego i Bernharda) po spojrzenie na cudze cierpienie (pisarstwo Gombrowicza i film Hanekego).

Lektury Porzuczka ciekawie prezentują taktyki radzenia sobie z bólem, który wpływa na podmiotowość cierpiącego. Chociaż w dyskursie maladycznym dominuje - jak sądzę - przekonanie, że ból intensyfikuje świadomość istnienia podmiotu i stanowi przypomnienie o ,ja", a nawet prowadzi do jego lepszego poznania ${ }^{26}$, Piotruś Lipskiego zostaje ukazany jako intrygująca strategia zniknięcia „ja". W świecie przedstawionym Bernharda wobec potężnej machiny szpitalnej bohater stara się ratować swoją jednostkowość dzięki przekuciu bólu w gniew. Teksty Gombrowicza traktowane są przez

${ }^{23}$ Monika Ładoń także docenia badawczy dystans w pisarstwie Sebastiana Porzuczka. Zob. EAdem: Kartografia (Nie)możliwego...

${ }^{24}$ Adaptuję pojęcie z medioznawstwa. Zob. M. BrzozowsKa-BrywczyńsKa: Polityka litości i reżimy reprezentacji. Dylematy widza cudzego cierpienia. „Kultura Współczesna" 2018, nr 4, s. 132-135.

${ }_{25}$ Por. E. Konończuk: Mapa w interdyscyplinarnym dialogu..., s. 259, 262.

26 Zob. K. Wieczorek: Samotność bólu..., s. 29-30; E. Lévinas: Czas i to, co inne. Przeł. J. Migasiński. Warszawa 1999, s. 67; T. SŁaweK: Czy ból uczy? Lekcja spojrzenia dolorycznego. W: Ból..., s. 12; Idem: "Ja bolę”..., s. 102; C. Czajкa: Człowiek jako cierpiace ciało w filozofii Johna D. Caputo. "Przegląd Filozoficzny” 2012, nr 2, s. 432; M. Szubert: Anatomia bólu. Ujęcie socjokulturowe. „Ethos” 2017, nr 4, s. 104; S. Weil: Świadomość nadprzyrodzona. Wybór myśli. Przeł. A. Olędzka-Frybesowa. Warszawa 1999, s. 290-292. 
Porzuczka jako skarbiec „afektywnego potencjału interioryzacji doznań" (s. 20), natomiast film Hanekego - jako próba empatycznego, czułego zbliżenia się do tego, kto pogrążony jest w bólu.

Pomimo wspomnianej, częstej rezygnacji z kontekstu historycznego autor proponuje bogate, wieloaspektowe, wrażliwe na niuanse interpretacje trudnych tekstów kultury. Porzuczek ma bardzo dobrze opanowany aparat analityczny, a jego wnioski są przekonujące, często odkrywcze. Rzadko można odczuć niedosyt. Doświadczam takiego, czytając - skądinąd imponującą - interpretację Miłości. Film (podobnie jak i cała twórczość Hanekego) absolutnie wymyka się jednoznaczności, dlatego z tym większym zaciekawieniem oczekiwałam uwag Porzuczka na temat końcowej sceny, lecz i one się „wymknęły". Autor stwierdza zwięźle, że finałowe morderstwo żony jest poza „etycznymi i ideologicznymi eksplikacjami” (s. 157) ${ }^{27}$. Czy można sobie wyobrazić problem właściwszy dla etyki, rozumianej jako teoria moralności? Odczytuję jednak zamilknięcie interpretatora właśnie przez pryzmat etyki. Powstrzymanie się od oceny postaw wszak jest uznawane za przejaw empatii ${ }^{28}$.

W końcowym rozdziale, w którym autor kreśli kulturową typografię bólu, a zatem przechodzi do ujęcia generalizującego, pojawiają się rozmaite teksty kultury: Czarnobylska modlitwa Swietłany Aleksijewicz, Pianistka Elfriede Jelinek, Wiek żelaza Johna Maxwella Coetzeego, Szklany klosz Sylvii Plath, Kanat Cierpienia i Osoba w depresji Davida Fostera Wallece'a, Mróz Thomasa Bernharda i Śmierć Ignacego Dąbrowskiego, Dziennik bez samogłosek Aleksandra Wata, Król Bólu i pasikonik Jacka Dukaja oraz film Funny Games Michaela Hanekego. Na tym etapie wywodu ich przywołanie z oczywistych względów ma bardziej zinstrumentalizowany charakter. A jednak momentami czytelnik chciałby pozostać nieco dłużej przy wymienionych dziełach. Czy przykładowo podejście bohaterów Czarnobylskiej modlitwy do cierpienia całej natury, także w wymiarze mikroświata, nie korespondowałoby pięknie z tymi aspektami, które autor wydobył, interpretując twórczość Gombrowicza?

Porzuczek we wstępie przyznaje, że jego mapa ma białe plamy. To wyznanie $\mathrm{w}$ pierwszym odruchu wzbudziło moje skojarzenie

${ }^{27}$ Moim zdaniem inspirującą interpretację podaje Danuta Prokulska-Balcerzak. Zob. Haneke łamie poczucie czasu. Rozmowa D. Bugalskiego z D. Prokulską-Balcerzak i T. Sobolewskim. https://www.polskieradio.pl/9/396/ Artykul/717707,Haneke-lamie-poczucie-czasu [dostęp: 1.06.2020].

${ }_{28}$ Zob. M. Szpunar: Niewrażliwa kultura. O chronicznej potrzebie wrażliwości we współczesnym świecie. „Kultura Współczesna” 2018, nr 4, s. 17; М. Окuрnік: W niewoli ciała..., s. 153. 
z Ulica krokodyli Schulza. Na mapie, znanej z opowiadania, biel, która tradycyjnie używana była do zakreślania nieodkrytych przestrzeni, staje się sposobem oznaczenia dzielnicy upadku. Mapa Porzuczka jest jednak inna. Autor co chwila odsłania to, co niegdyś uchodziło za tabu. Jego interpretacje nie odrzucają tematu „pasaży ohydności” (s. 33) i perwersji, ale także wielu innych, niezręcznych aspektów: (non)sensu cierpienia, dyskryminacji, wykorzystania bólu dla władzy (także płciowej dominacji), wątpliwego etycznie statusu widza obserwatora czyjegoś cierpienia czy ponowoczesnej „konsumpcji cierpienia” (s. 182) i „fetyszyzacji przemocy” (s. 187) w celu rozrywki. Patronują mu w tym: Susan Sontag, Michel Foucault, Elaine Scary, Javier Moscoso, Judith Butler i wielu innych.

Białymi plamami na mapie pozostaje wymiar metafizyczny czy eschatologiczny, co wynika zapewne w sporym stopniu z wyboru analizowanych tekstów. Wobec ciszy zaświatów względną otuchę w cierpieniu może przynieść jedynie „paliatywny charakter literatury" (s. 55) czy szerzej: sztuki. Pomaga bowiem niekiedy wyrwać się z solipsyzmu, przezwyciężając kryzys komunikacji. Pisanie i działanie artystyczne jawi się więc jako „dar łaski” (s. 134).

Mapowanie bólu istotnie zawiera kilka białych plam i niemało ryzykownych (a może po prostu odważnych?) rozwiązań, lecz trudno byłoby wyobrazić sobie projekt tak ambitnie zakrojony, który zdołałby uwzględnić całe bogactwo poruszanej problematyki. Konieczna niepełność może mieć nawet wymiar szlachetny, ponieważ chroni przed dążeniami uzurpatorskimi względem tak delikatnej sfery ludzkich doznań. Podtrzymuję zatem swoją opinię, że książka Porzuczka jest cenną mapą dla wszystkich, którzy pragną zagłębić się $\mathrm{w}$ doloropoetykę - dla tych bardziej i mniej zaawansowanych tropicieli bólu w kulturze. To propozycja inspirująca, która może zachęcić do stopniowego, odbywającego się w duchu empatii, odsłaniania kolejnych tajemnic.

\section{Bibliografia}

Adorno T.W.: Dialektyka negatywna. Przeł. K. Krzemieniowa. Warszawa 1986. Augustyn, św.: Dialogi filozoficzne. Przeł. A. Świderkówna. Kraków 1999.

Borowicz J.: Ciało we fragmentach, strzepki historii. Post-Zagładowe perwersje Leo Lipskiego. „Teksty Drugie” 2017, nr 2, s. 356-374.

Bonuszкоwsкa I.: Sygnatury choroby. Literatura defektu w ukraińskim modernizmie.

Warszawa 2018.

Bourke J.: The Story of Pain. From Prayer to Painkillers. Oxford 2014. 
Ból. Red. A. Czekanowicz, S. Rosiek. Gdańsk 2004.

BrüCKner A.: Stownik etymologiczny języka polskiego. Warszawa 1985.

Brzozowska-Brywczyńska M.: Polityka litości i reżimy reprezentacji. Dylematy widza cudzego cierpienia. „Kultura Współczesna” 2018, nr 4, s. 126-140.

Cuber M.: Proza Leo Lipskiego. Poetyka i egzystencja. Katowice 2006. https://rebus. us.edu.pl/bitstream/20.500.12128/4960/1/Cuber_Proza_Leo_Lipskiego.pdf [dostęp: 31.05.2020].

Czajka C.: Człowiek jako cierpiace ciało w filozofii Johna D. Caputo. „Przegląd Filozoficzny" 2012, nr 2, s. 425-440.

Descartes R.: Rozprawa o metodzie. Przeł. T. Boy-Żeleński. Warszawa 2008.

Descartes R.: Zasady filozofii. Przeł. I. Dąmbska. Warszawa 1960.

Durкheim É.: Elementarne formy życia religijnego. System totemiczny w Australii. Przeł. A. Zadrożyńska. Warszawa 1990.

Fragmenty dyskursu maladycznego. Red. M. Ganczar, I. Gielata, M. Ładoń. Gdańsk 2019.

Gert B., Culver Ch.M., Denner Clouser K.: Bioetyka. Ujęcie systematyczne. Przeł. М. СнојNAскі. Gdańsk 2009.

Gogacz M.: Filozoficzne rozważania o rozpaczy $i$ nadziei. „Studia Philosophiae Christianaes" 1983, nr 2, s. 151-182.

Haneke tamie poczucie czasu. Rozmowa D. Bugalskiego z D. Prokulską-Balcerzak i T. Sobolewsкim. https://www.polskieradio.pl/9/396/Artykul/717707,Hanekelamie-poczucie-czasu [dostęp: 1.06.2020].

Hinc S.: Emile Durkheim: edukacja moralna jako podstawa egzystencji. „Przegląd Naukowo-Metodyczny. Edukacja dla Bezpieczeństwa" 2008, nr 1, s. 13-25.

Janowski Z.: Index augustino-cartésien. Textes et commentaire. Paris 2000.

JüNGer E.: O bólu. Przeł. J. РRокоріuк. „Literatura na Świecie” 1986, nr 9, s. $177-230$.

Kobieta, literatura, medycyna. Red. A. Galant, A. Zawiszewska. Szczecin 2016.

Konończuk E.: Mapa w interdyscyplinarnym dialogu geografii, historii i literatury. „Teksty Drugie” 2011, nr 5, s. 255-264.

Lévinas E.: Czas i to, co inne. Przeł. J. Migasiński. Warszawa 1999.

Lipszyc A.: Część śmierci: bierny frankizm i czarna gnoza w „Piotrusiu” Leo Lipskiego. „Teksty Drugie" 2017, nr 2, s. 333-355.

Ładoń M.: Choroba jako literatura. Studia maladyczne. Katowice 2019.

Ładoń M.: Kartografia (Nie)możliwego. „artPapier” 2020, nr 13. http://artpapier. com/index.php?page=artykul\&wydanie=397\&artykul=7948\&kat=15 [dostęp: 9.07.2020].

Ładoń M.: Ślady Barthes'a: migrena, symbolizacja, fragment (słowo wstępne). W: Fragmenty dyskursu maladycznego. Red. M. Ganczar, I. Gielata, M. Ładoń. Gdańsk 2019, s. 7-13.

Musiaє Ł.: Laboratorium bólu (Ernst Jünger). W: Idem: O bólu. Pięć rozważań w poszukiwaniu autora. Poznań 2016, s. 79-96.

Nycz R.: Lekcja Adorna. „Teksty Drugie” 2012, nr 3, s. 34-50.

Окирлік M.: W niewoli ciała. Doświadczenie utraty zdrowia i jego reprezentacje. Kraków 2018. 
Porzuczek S.: Mapowanie bólu. Lektura - spojrzenie - afekt. Kraków 2020.

Pyszkowska J.: Cierpienie chorych u kresu życia. W: W poszukiwaniu sensu cierpienia - dialog interdyscyplinarny. Red. ks. A. Bartoszeк. Katowice-Tarnów 2006.

SŁaweK T.: Czy ból uczy? Lekcja spojrzenia dolorycznego. W: Ból. Red. A. CzeKanowicz, S. Rosiek. Gdańsk 2004, s. 11-21.

SŁaWeK T.: „Ja bolę”. Boleść i terapia. W: Fragmenty dyskursu maladycznego. Red. M. Ganczar, I. Gielata, M. Ładoń. Gdańsk 2019, s. 89-107.

SŁAwEK T.: Nadzieja rozbitka. https://www.youtube.com/watch?feature=youtu.be $\& v=K k 6 e Q N S k 7 u o \& f b c l i d=I w A R 1 q m k I m V t R U Z P k 5 z K 2 d d O M D 6 O h 1 S K A C-$ cYM_Ck9maCEyBaPu4D3XA_TjXE\&app=desktop [dostęp: 30.05.2020].

SzACKi J.: Historia myśli socjologicznej. Warszawa 2002.

Szpunar M.: Niewrażliwa kultura. O chronicznej potrzebie wrażliwości we współczesnym świecie. „Kultura Współczesna” 2018, nr 4, s. 13-23.

Szubert M.: Anatomia bólu. Ujęcie socjokulturowe. „Ethos” 2017, nr 4, s. 102-117.

Szubert M.: Dyskurs maladyczny - perspektywy badawcze. W: Fragmenty dyskursu maladycznego. Red. M. Ganczar, I. Gielata, M. Ładoń. Gdańsk 2019, s. 17-35.

Ślıwiński T.: Źródła filozofii Descartes'a w myśli św. Augustyna. „Acta Universitatis Lodziensis Folia Philosopica" 2011, nr 24, s. 45-72.

Tatarkiewicz W.: Historia filozofii. T. 1: Filozofia starożytna i średniowieczna. Warszawa 2004.

Weil S.: Świadomość nadprzyrodzona. Wybór myśli. Przeł. A. OlęDzKa-Frybesowa. Warszawa 1999.

WieczoreK K.: Samotność bólu, ból samotności. „Ethos” 2017, nr 4, s. 19-48.

Ewelina Suszek - doktor, adiunkt w Państwowej Wyższej Szkole Zawodowej w Tarnowie, współpracuje również z Wyższą Szkołą Ekonomiczno-Humanistyczną w Bielsku-Białej. Jej zainteresowania badawcze koncentrują się na polskiej poezji współczesnej, a także współczesnej filozofii. Opublikowała dwie książki: Szybkość, pośpiech, kompresja. „Poetyka przyśpieszenia” w poezji Krystyny Miłobędzkiej (Katowice 2014) oraz Figuracje braku i nieobecności. Miłobędzka - Białoszewski - Kozioł (Kraków 2020). Współredaktorka tomów zbiorowych: Przygody nierozumu: szaleństwo - myśl - kultura (Katowice 2012) i Kontrinterpretacje (Kraków 2018).

e-mail: suszek.ewelina@gmail.com 